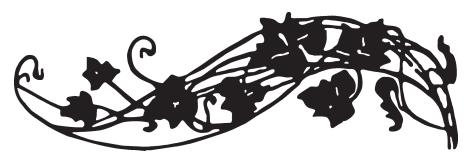

„CHOWANNA” 2021, T. 1 (56)

ISSN $2353-9682$

(c) (i) (2)

https://doi.org/10.31261/CHOWANNA.2021.56.01

s. $1 \mathrm{z} 28$

Anna Studenska

Uniwersytet Śląski w Katowicach

(iD) https://orcid.org/0000-0002-6699-9510

\title{
Preferencje uczących się wobec czynności nauczyciela wspierających autonomię \\ w opanowywaniu wiedzy i umiejętności
}

\author{
Students' Preferences \\ for the Fostering of Their Learning Autonomy by Teachers
}

\begin{abstract}
Assisting students in the process of becoming independent learners is regarded as one of the goals of education. Achieving this goal has currently become more urgent because of the increasing amount of available information. Moreover, the COVID-19 pandemic has made common the usage of remote education, which often demands more independent decisions concerning the acquisition of skills and knowledge on the part of the learner than in the classes where the teacher is in person available for students. Research shows that people differ in their preferences for situations which demand making independent decisions from them. Also, there are also a few instruments which allow to measure learners' preferences for the teacher's activities aimed at increasing the learning autonomy of class participants. For this reason, the aim of this study has been to investigate students' preferences as regards the fostering of their learning autonomy by teachers. Fostering Learner Independence Inventory was constructed for the purpose of the research. Data was gathered in 2019 and 2020 among 137 and 87 university students respectively. The results have shown that out of the analyzed teachers' activities aimed at fostering learners' autonomy the ones most preferred by the students who participated in the research were listening to class participants and providing them with the opportunity to express their opinions. The results from the two research groups show a significant increase in the data gathered in 2021 in comparison to the data from 2019 in the respondents' preferences for the teacher's messages expressing their understanding of students' experiences of difficulties in learning and motivating them to study. Practical conclusions from the research results have been drawn.
\end{abstract}


Keywords: fostering learning autonomy, preferences for fostering learning autonomy, learning autonomy

Wstęp

W lutym 2020 roku w większości państw świata ujawniono występowanie odmiany koronawirusa powodującej chorobę COVID-19. Próby ograniczenia rozprzestrzeniania się wirusa koncentrowały się (i nadal koncentrują) na tworzeniu warunków niesprzyjających reprodukcji SARS-CoV-2. Do tego typu działań zapobiegawczych należy ograniczanie spotkań w dużych grupach, w tym szkołach. Aby zrealizować wytyczne, w placówkach edukacyjnych wdrożono zdalne nauczanie ${ }^{1}$. W ogólnopolskich badaniach podjętych przez zespół z Wydziału Pedagogicznego Uniwersytetu Warszawskiego wykazano, że uczniowie objęci zdalnym nauczaniem brak kompetencji w zakresie samodyscypliny, systematyczności, zarządzania czasem oraz samodzielnego uczenia się postrzegają jako jedno z najważniejszych utrudnień w opanowywaniu treści nauczania ${ }^{2}$. W niniejszym artykule przedstawiono wyniki badań preferencji osób uczących się wobec czynności nauczycielskich pobudzających do samodzielnego nabywania wiedzy i umiejętności oraz wnioski z tych badań.

W klasycznym ujęciu wychowania jako relacji pedagogicznej wychowawca w realizowaniu swojej roli jako osoby przekazującej wychowankowi kulturę społeczeństwa powinien uwzględnić potrzeby i zainteresowania swojego podopiecznego oraz dać mu przestrzeń do samodzielnego zapoznania się z otrzymywanymi treściami i ich testowania $^{3}$. W ujęciu wychowania jako symbolicznej interakcji za priorytet uważa się rozwój osobowości wychowanka; główną rolą wychowawcy jest wspieranie podopiecznego w naśladowaniu modeli zachowań przez udzielanie mu bezpośredniej pomocy, jak i dawanie możliwości podejmowania samodzielnych prób działania ${ }^{4}$. Samodzielność myślenia i działania uważa się za jedną z kluczowych kompetencji człowie-

${ }^{1}$ J. Pyżalski: Wstęp. W: Edukacja w czasach pandemii wirusa COVID-19. Z dystansem o tym, co robimy obecnie jako nauczyciele. Red. J. Pyżalski. PDF. Edukacja, Warszawa 2020, s. 2-6.

${ }^{2}$ M. Plebańska, A. Szyller, M. Sieńczewska: Edukacja zdalna w czasach COVID-19. Raport z badania. Czerwiec 2020. https://kometa.edu.pl/uploads/publication/941/24a2_A_a_nauczanie_zdalne_oczami_nauczycieli_ i_uczniow_RAPORT.pdf?v2.8COVID [dostęp: 20.06.2021].

${ }^{3}$ F.W. Kron: Pedagogika. Kluczowe zagadnienia Podręcznik akademicki. Przekł. E. Cieślik. Gdańskie Wydawnictwo Psychologiczne, Sopot 2012, s. 185.

${ }^{4}$ Ibidem, s. 199-200. 
$\mathrm{ka}^{5}$. W polskiej dydaktyce od dawna podkreśla się ważność wspierania samodzielności wychowanków w uczeniu się ${ }^{6}$ zwraca się uwagę na istotę samokształcenia uczniów, które ma prowadzić do wielostronnego rozwoju ich osobowości ${ }^{7}$. Jednym z warunków rozwoju indywidualności i osobowości człowieka jest stworzenie mu możliwości wykorzystania opanowanych przez niego treści dzięki ich samodzielnemu doświadczaniu i przeżywaniu, a przez to wykształcenia w sobie poczucia sprawstwa ${ }^{8}$. Jak podkreślają Hanna Dumont oraz David Istance9, we współczesnych społeczeństwach opartych na wiedzy istotne jest wspieranie uczniów w aktywnym angażowaniu się we własne uczenie się, czyli kształtowanie w nich kompetencji samoregulacyjnych oraz odnoszących się do wiedzy o własnym uczeniu się ${ }^{10}$.

W kontekście wagi, jaką dla rozwoju młodego człowieka ma nabycie kompetencji do decydowania o własnym uczeniu się, oraz konieczności korzystania z tej umiejętności w czasie pandemii, która wymusza większą niezależność w nabywaniu wiedzy i umiejętności, wydało się istotne stwierdzenie, $\mathrm{w}$ jakim stopniu dostępne dla nauczycieli sposoby wspierania samodzielnego uczenia się są preferowane przez osoby uczące się. Aby uzyskać informacje na ten temat, zaplanowano przeprowadzenie badań empirycznych dotyczących preferencji osób dorastających wobec takich nauczycielskich sposobów wspierania uczniowskiej autonomii w uczeniu się, jak: umożliwienie uczniom wyrażania własnych opinii, decydowania o sposobie wykonywania zadań i działań podejmowanych w czasie zajęć, formułowanie komunikatów wspierających, motywujących i informujących o poziomie wykonanej

${ }^{5}$ J.P. Sawiński: Jak zwiększyć skuteczność szkolnej edukacji. Poradnik dla nauczycieli i edukatorów. Cz. 2. Difin, Warszawa 2016, s. 109.

${ }^{6}$ A.B. Dobrowolski: Nowa dydaktyka. Oprac. komitet redakcyjny. Wstępem zaopatrzył W. Okoń. Państwowe Zakłady Wydawnictw Szkolnych, Warszawa 1960, s. 41.

${ }^{7}$ J. Półturzycki: Dydaktyka dla nauczycieli. Adam Marszałek, Toruń 1999, s. 161.

${ }^{8}$ W. Kojs, E. Urban-Kojs: Społeczne, osobowe i pedagogiczne aspekty edukacji całożyciowej człowieka. W: Czas społeczny akademickiego uczestnictwa $w$ rozwoju $i$ doskonaleniu civil society: księga jubileuszowa dedykowana profesorowi Andrzejowi Radziewiczowi-Winnickiemu w 65. rocznicę urodzin. Red. E. Syrek. Wydawnictwo Uniwersytetu Śląskiego, Katowice 2010, s. 312-324.

${ }^{9} \mathrm{H}$. Dumont, D. Istance: Analiza i tworzenie środowisk uczenia się XXI wieku. W: Istota uczenia się. Wykorzystanie wyników badań w praktyce. Red. H. Dumont, D. Istance, F. Benevides. Wstęp A. Janowski. Tłum. Z. Janowska. Wolters Kluwer Polska, Warszawa 2013, s. 35-59. https://doi.org/10.1787/9789264201606-pl.

10 D. Istance, H. Dumont: Przyszłość środowisk uczenia się XXI wieku. W: Istota uczenia się..., s. 479-513. 
pracy, a także uzasadniających proponowane działania, ponadto zachęcanie do brania udziału w rozwiązywaniu problemów klasowych i szkolnych.

\section{Przegląd literatury}

Autonomia w nabywaniu wiedzy i umiejętności uważana jest za „zdolność do kierowania własnym uczeniem się lub do przejęcia odpowiedzialności za własne uczenie się"11. Wiąże się z samodzielnym wyborem treści uczenia się, zachowań związanych planowaniem, przebiegiem oraz oceną uczenia się oraz kontrolowaniem procesów poznawczych warunkujących nabywanie wiedzy i umiejętności ${ }^{12}$. Analiza autonomicznie motywowanego uczenia się często podejmowana jest w ramach teorii samookreślenia ${ }^{13}$. Teoria ta zakłada, iż autonomia jednostki, obok poczucia kompetencji oraz znaczących relacji z innymi osobami, jest podstawową potrzebą człowieka ${ }^{14}$ i ma miejsce wtedy, gdy osoba działa w poczuciu, że robi to $\mathrm{z}$ własnej woli ${ }^{15}$.

Wspieranie autonomii jest określane przez Johnmarshalla Reeve'a jako „wysiłek nauczania mającego zapewnić uczącym się takie środowisko fizyczne oraz takie relacje nauczyciel - uczeń, które zaspokajają ich potrzebę autonomii. Jest ono zespołem uczuć między osobami oraz zachowań, które prowadzący zajęcia zapewnia podczas nauczania, a które mają na celu przede wszystkim zidentyfikowanie, następnie ożywienie i pielęgnowanie, a w końcu rozwinięcie i umocnienie zasobów motywacyjnych osób uczących się"16. Nauczyciel wspierający autonomię ucznia przyjmuje rolę mentora, doradcy, osoby pomagającej uczniowi osiąg-

${ }^{11}$ P. Benson: Teaching and Researching Autonomy in Language Learning. Longman, Harlow 2001, s. 47. Jeśli nie podano inaczej, tłumaczenia fragmentów - A.S.

12 Ibidem, s. 50, 76-103.

${ }^{13}$ F. Guay, C.F. Ratelle: Optimal Learning in Optimal Contexts: The Role of Self-Determination in Education. „Canadian Psychology” 2008, vol. 49 (3), s. 233240. https://doi.org/10.1037/a0012758.

${ }^{14}$ E.L. Deci, R.M. Ryan: Self-Determination Theory: A Macrotheory of Human Motivation, Development, and Health. „Canadian Psychology” 2008, vol. 49 (3), s. 182-185. https://doi.org/10.1037/a0012801.

${ }^{15}$ D.N. Stone, E.L. Deci, R.M. Ryan: Beyond Talk: Creating Autonomous Motivation Through Self-Determination Theory. "Journal of Genera Management" 2009, vol. 34 (3), s. 75-91. https://doi.org/10.1177/030630700903400305.

${ }^{16}$ J. Reeve: Autonomy Supportive Teaching: What It Is, How to Do It. W: Building Autonomous Learners. Perspectives from Research and Practice Using Self-Determination Theory. Eds. W.Ch. Liu, J.Ch.K. Wang, R.M. Ryan. Springer, London 2016, s. 130. https://doi.org/10.1007/978-981-287-630-0. 
nąć cele uczenia się ${ }^{17}$. Wojciech Kojs zwraca uwagę na to, że wspieranie samodzielności ucznia w zdobywaniu wiedzy i umiejętności powinno odnosić się do całego zestawu jego działań: od planowania działań, przez ich realizację, kontrolę, korektę tego, co udało się osiągnąć, aż do ostatecznej oceny uzyskanego efektu ${ }^{18}$. Do zachowań nauczyciela, które uznano za wspierające poczucie autonomii uczniów, należą: dawanie uczniom możliwości wyboru, dokonywanie powiązań celów lekcji z celami uczniów, dawanie uczniom możliwości modyfikowania zadań tak, by odpowiadały ich celom, wyjaśnianie uczniom, dlaczego proponuje się im określoną drogę postępowania, unikanie w komunikatach do uczniów języka wskazującego na kontrolę, wyrażanie zrozumienia dla trudności oraz negatywnych emocji doświadczanych przez uczniów oraz pozwalanie uczniom, by pracowali we własnym tempie ${ }^{19}$. Za wspierające samodzielność uczniów w nabywaniu wiedzy i umiejętności uważa się również: informowanie uczniów o tym, na jakim poziomie poradzili sobie z zadaniem ${ }^{20}$, tłumaczenie, dlaczego wykonywane zadania są ważne, oraz dawanie uczniom swobody wypowiedzi ${ }^{21}$, oferowanie uczniom możliwości wyboru zadań do rozwiązania, grupy osób, w jakiej będą pracować, sposobu wykonania zadań, używanych materiałów, a także stawianie uczniów przed problemem do rozwiązania, pytanie ich o powody wyboru takiego, a nie innego sposobu rozwiązania problemu oraz pobudzanie ich do oceny własnej pracy ${ }^{22}$. Sposoby wspierania uczniów w autonomicznym uczeniu się służą więc pobudzaniu ich do

${ }^{17}$ M. Ciekanski: Fostering Learner Autonomy: Power and Reciprocity in the Relationship Between Language Learner and Language Learning Adviser. „Cambridge Journal of Education” 2007, vol. 37 (1), s. 111-127. https://doi. org/10.1080/03057640601179442.

${ }_{18}$ W. Kojs: Edukacja i pedagogika $w$ społeczeństwie wiedzy - wybrane zagadnienia. „Chowanna” 2012, nr 2 (39), s. 21-37.

${ }^{19}$ H. Jang, J. Reeve, M. Halusic: A New Autonomy-Supportive Way of Teaching That Increases Conceptual Learning: Teaching in Students' Preferred Ways. „The Journal of Experimental Education" 2016, vol. 84 (4), s. 686-701. https://doi. org/10.1080/00220973.2015.1083522.

${ }^{20}$ E.A. Skinner, M.J. Belmont: Motivation in the Classroom: Reciprocal Effects of Teacher Behavior and Student Engagement Across The School Year. "Journal of Educational Psychology" 1993, vol. 85 (4), s. 571-581. https://doi.org/10.1037/00220663.85.4.571.

${ }^{21}$ A. Assor, H. Kaplan, G. Roth: Choice Is Good, but Relevance is Excellent: Autonomy-Enhancing and Supressing Teacher Behaviours Predicting Students' Engagement in Schoolwork. „British Journal of Educational Psychology” 2002, vol. 72, s. 261-278. https://doi.org/10.1348/000709902158883.

${ }^{22}$ C.R. Stefanou et al.: Supporting Autonomy in the Classroom: Ways Teachers Encourage Student Decision Making and Ownership. „Educational Psychologist” 2004, vol. 39 (2), s. 97-110. https://doi.org/10.1207/s15326985ep3902_2. 
podejmowania samodzielnych decyzji związanych z zewnętrznymi warunkami uczenia się oraz kontrolą zewnętrznych zachowań, a także wewnętrznych procesów poznawczych, emocjonalnych i motywacyjnych, które prowadzą do opanowania wiedzy i umiejętności.

Na podstawie klasyfikacji nauczycielskich zachowań wspierających niezależność w uczeniu się opracowano skale mierzące poziom wsparcia, jaki uczniowie otrzymują w samodzielnym nabywaniu wiedzy i umiejętności. Przykładem takiego narzędzia może być Skala Wsparcia Autonomii Ucznia, opracowana przez Aytungę Oğuz ${ }^{23}$. Skala składa się z 17 stwierdzeń ocenianych na pięciostopniowej skali (w zakresie od „nigdy” do „zawsze”). Za pomocą konfirmacyjnej analizy czynnikowej potwierdzono, że mierzy wspieranie trzech procesów: myślenia i odczuwania, uczenia się oraz samooceny uczniów. Akram Nayernia opracowała Skalę Wsparcia Samodzielności przeznaczoną dla zdalnego uczenia się. Dane zebrane przez autorkę pozwoliły na opracowanie modelu, w którym jako składowe wspierania uczniowskiej autonomii przez nauczycieli uwzględniono ograniczanie kontrolowania uczniów i kształtowanie ich niezależności, przyznawanie uczniom możliwości negocjowania rodzaju rozwiązywanych zadań oraz dostarczanie instrukcji-wskazówek, okazywanie uczniom, że jest się świadomym doświadczanych przez nich uczuć, zaznajamianie uczniów z kryteriami oceny oraz ze strukturą materiału, wspieranie uczniów przygotowaniem lekcji tak, by pobudzała ich samodzielność, szanowanie autentyczności uczących się, a także udzielanie uczniom pomocy techniczneje ${ }^{24}$.

Badania wykazały, że wspieranie autonomii uczniów przez nauczyciela przynosi korzystne skutki: zwiększa poczucie motywacji wewnętrznej uczniów, powoduje poprawę ich wyników w nauce, a także wiąże się z doświadczaniem pozytywnych emocji ${ }^{25}$. Wzrost motywacji wewnętrznej oraz zaangażowania uczniów w wykonywanie zadań był większy, gdy stawiano uczniów przez zadaniami problemowymi oraz gdy proszono, by uzasadnili proponowany przez siebie sposób rozwiązania, niż wtedy, gdy mogli decydować o organizacji pracy w klasie czy wyborze celów działania i środków do ich realizacji ${ }^{26}$. Uzyskane w toku badania dane pokazały, że im więcej wsparcia własnej autono-

${ }^{23}$ A. Oğuz: Developing a Scale for Learner Autonomy Support. „Educational Sciences: Theory and Practice" 2013, vol. 13 (4), s. 2187-2194.

${ }^{24}$ A. Nayernia: Development and Validation of an E-teachers' Autonomy-Support Scale: A SEM Approach. „International Journal of Language Studies” 2020, vol. 14 (2), s. 117-134.

${ }^{25}$ E.L. Deci, R.M. Ryan: Optimizing Students' Motivation in the Era of Testing and Pressure: A Self-Determination Theory Perspective. W: Building Autonomous Learners..., s. 9-30.

${ }^{26}$ C.R. Stefanou et al.: Supporting Autonomy in the Classroom..., s. 97-110. 
mii ze strony nauczyciela doświadcza uczeń, tym silniejsze jest jego poczucie własnej skuteczności, a im silniejsze jest to poczucie, tym głębiej przetwarza on informację podczas uczenia się $e^{27}$. Mintra Phithakmethakun oraz Sumalee Chinokul za pomocą kwestionariusza zebrały opinie uczestników kursu języka obcego wspierającego autonomię uczenia się na temat tych zajęć. Wyniki badania odpowiedzi na zawarte $\mathrm{w}$ kwestionariuszu pytania wskazały na poczucie wzrostu motywacji do uczenia się u osób, które brały udział w kursie ${ }^{28}$. Istotnym warunkiem preferowania nauczycielskich prób wspierania samodzielnego myślenia uczniów w czasie zajęć okazała się atmosfera panująca w klasie dająca uczestnikom poczucie bycia akceptowanymi przez prowadzącego zajęcia oraz członków grupy ${ }^{29}$.

We współczesnych czasach badania dotyczące wspierania autonomii uczenia się prowadzone są najczęściej w kontekście wykorzystania nowych technologii w edukacji oraz glottodydaktyce. Tworzenie przez uczniów wirtualnych przestrzeni z wybranymi przez nich obiektami, a następnie wykorzystanie języka obcego do mówienia o tych przestrzeniach zaowocowały poczuciem autonomii u uczniów oraz stosowaniem przez nich różnorodnych strategii uczenia się ${ }^{30}$. Dane na temat opinii osób uczących się języków obcych za pomocą kursów na platformie Moodle wskazują, że respondenci postrzegają taki sposób nabywania umiejętności i wiedzy jako sprzyjający nabywaniu umiejętności uczenia się, zauważają jednak ważną rolę, jaką w tym procesie odgrywają interakcje z nauczycielem oraz wskazówki, których może on udzielići ${ }^{31}$.

${ }^{27}$ J. Zhao, Y. Qin: Perceived Teacher Autonomy Support and Students' Deep Learning: The Mediating Role of Self-Efficacy and the Moderating Role of Perceived Peer Support. „Frontiers in Psychology” 2021, s. 1-11. https://doi.org/10.3389/ fpsyg.2021.652796.

${ }^{28}$ M. Phithakmethakun, S. Chinokul: Autonomy-Supportive English Language Instruction: An Experimental Study on Students' Motivation in English Language Classroom. „Language Education and Acquisition Research Network Journal" 2020, nr 1 (13), s. 94-113. https://files.eric.ed.gov/fulltext/EJ1242978. pdf [dostęp: 20.06.2021].

${ }_{29}$ T.L. Wallace, H.C. Sung: Student Perceptions of Autonomy-Supportive Instructional Interactions in the Middle Grades. The Journal of Experimental Education 2017, vol. 85 (3), s. 425-449. https://doi.org/10.1080/00220973.20 16.1182885 .

${ }^{30}$ Y.L. Yeh, Y.J. Lau: Fostering Student Autonomy in English Learning Through Creations in a 3D Virtual World. „Educational Technology Research \& Development" 2018, vol. 66, s. 693-708.

${ }^{31}$ D. Gulbinskienè, M. Masoodi, J. Šliogerienè: Moodle as Virtual Learning Environment in Developing Language Skills, Fostering Metacognitive Awareness and Promoting Learner Autonomy. „Pedagogika” 2017, T. 127, nr 3, s. 176-185. https:// doi.org/10.15823/p.2017.47. 
Na temat podejmowania decyzji piszą Patrick N. Beymer i Margareta Maria Thomson. Wymieniają oni okoliczności, w jakich osoby preferują możliwość dokonania wyboru. Ludzie wolą dysponować prawem do dokonania wyboru spośród różnych rodzajów działania, gdy czują, że mają wystarczające kompetencje, by poradzić sobie z zadaniami, a spośród tych zadań mają wskazać to, z którym się zmierzą, gdy są zainteresowani proponowanymi czynnościami oraz przekonani, że dokonany wybór rzeczywiście ma znaczenie dla uzyskania upragnionego efektu. Osoby wolą mieć możliwość wyboru (niż jej nie mieć), gdy opcji, spośród których można wybierać, nie jest dużo, a jeśli jest ich wiele, to są one pogrupowane, gdy opcje te są wybierającym znane, różnią się od siebie niewieloma cechami, gdy nie trzeba dokonywać więcej niż jednego wyboru naraz i nie jest konieczne uzasadnianie podjętej decyzji, a wybór nie wiąże się z dużą odpowiedzialnością ${ }^{32}$.

Preferowanie sytuacji wyboru (zamiast braku wyboru) okazało się także związane z cechami indywidualnymi osoby. Te jednostki, które mają tendencję do porównywania się z innymi oraz nie sformułowały jasnych kryteriów wyboru, bardziej cenią sytuacje, w których nie muszą same decydować, niż te, w których można wybierać. Wysoki poziom preferencji wobec dokonywania samodzielnych wyborów obserwuje się u osób mających tendencję do wyszukiwania w istniejących warunkach wskazówek do dalszego działania, rozpatrywania niewielu możliwych dróg rozwiązań problemu, szybkiego osiągania celu oraz zorientowanych na działanie ${ }^{33}$, a także nastawionych na radzenie sobie samemu, lecz po zasięgnięciu wskazówek od innych osób ${ }^{34}$.

Przegląd literatury na temat autonomii w zakresie uczenia się pozwala na stwierdzenie, że:

- niezależność uczenia się jest we współczesnych czasach jedną z ważniejszych kompetencji, jakie mogą nabyć młodzi ludzie;

- funkcjonowanie w środowisku sprzyjającym samodzielności w opanowywaniu wiedzy i umiejętności może być korzystne dla efektów uczenia się oraz dobrostanu uczniów;

${ }^{32}$ P.N. Beymer, M.M. Thomson: The Effects of Choice in the Classroom: Is There Too Little or Too Much Choice? „S Support for Learning” 2015, vol. 30 (2), s. 105120. https://doi.org/10.1111/1467-9604.12086.

${ }^{33}$ A. Pierro et al.: Regulatory Mode Preferences for Autonomy Supporting Versus Controlling Instructional Styles. „British Journal of Educational Psychology” 2009, vol. 79 (4), s. 599-615. https://doi.org/10.1348/978185409X412444.

${ }^{34}$ S. Komissarouk, G. Harpaz, A. Nadler: Dispositional Differences in Seeking Autonomy-or Dependency-Oriented Help: Conceptual Development and Scale Validation. „Personality and Individual Differences” 2017, vol. 108, s. 103-112. https://doi.org/10.1016/j.paid.2016.12.019. 
- istnieją czynniki, które powodują, że osoby mogą różnić się preferencjami wobec środowiska wymagającego samodzielnego działania;

- niewiele narzędzi badawczych pozwala zmierzyć poziom preferencji uczniów wobec działań nauczyciela mających na celu kształtowanie ich autonomii w uczeniu się.

Z danych tych wynika, że problem preferencji osób uczących się wobec działań nauczycielskich wspierających ich autonomię nie jest dostatecznie rozpoznany i wymaga dalszych badań. Istotne wydaje się zwłaszcza rozpoznanie różnic w preferencjach uczestników zajęć wobec różnych sposobów oraz warunków wspierania ich samodzielności w opanowywaniu wiedzy i umiejętności, a szczególnie komunikatów, jakie otrzymują od nauczyciela.

\section{Problem i cel badań własnych}

Problem główny badań własnych zawarto w pytaniu: Jaki jest deklarowany poziom preferencji badanych studentów wobec sposobów wspierania ich autonomii uczenia się przez nauczycieli? Za cel badań własnych przyjęto dokonanie analizy poziomu preferencji uczestników zajęć wobec stosowanych przez nauczycieli sposobów wspierania autonomii osób uczących się.

$\mathrm{W}$ obrębie wymienionego problemu głównego postawiono następujące szczegółowe pytania badawcze:

1. Które nauczycielskie zachowania wspierające autonomię ucznia są najchętniej preferowane przez uczestników badań?

2. Które nauczycielskie zachowania wspierające autonomię ucznia są najmniej chętnie preferowane przez uczestników badań?

3. Czy istnieją różnice $\mathrm{w}$ wynikach przeprowadzonych $\mathrm{w}$ grupach osób badanych w 2019 oraz 2021 roku pomiarów preferencji nauczycielskich zachowań wspierających autonomię ucznia?

4. Które sposoby wspierania autonomii ucznia przez nauczyciela badani w 2021 roku wskazują jako te, które w ubiegłych 12 miesiącach zaczęli bardziej preferować?

5. Które sposoby wspierania autonomii ucznia przez nauczyciela badani w 2021 roku wskazują jako te, które w ubiegłych 12 miesiącach zaczęli mniej preferować?

Zmiennymi analizowanymi w badaniach własnych były wybrane nauczycielskie sposoby wspierania autonomii uczniów w nabywaniu wiedzy i umiejętności.

Ze względu na zwiększenie konieczności samodzielnego uczenia się w okresie pandemii COVID-19 podczas poszukiwania odpowiedzi na 
trzecie pytanie badawcze postanowiono sprawdzić, czy istnieją różnice między wynikami pomiarów przeprowadzonych w roku 2019 oraz tych z roku 2021. Sformułowano hipotezy zakładające, że oceny własnych preferencji osób badanych w roku 2019 oraz w roku 2021 będą różniły się wobec następujących sposobów wspierania autonomii ucznia:

- bycie wysłuchanym przez nauczyciela i posiadanie swobody wypowiedzi (hipoteza 1);

- otrzymywanie od nauczyciela informacji zwrotnej o poziomie wykonania zadań (hipoteza 2);

- kierowanie przez nauczyciela do uczniów komunikatów motywujących do pracy oraz przekazujących wiarę w możliwości uczniów (hipoteza 3);

- uzasadnianie przez nauczyciela proponowanego uczniom sposobu działania (hipoteza 4);

- umożliwianie uczniom przez nauczyciela decydowania o sposobie wykonywania zadań (hipoteza 5);

- wspieranie przez nauczyciela samodzielności uczniów w rozwiązywaniu problemów (hipoteza 6);

- zachęcanie uczniów przez nauczyciela do samodzielności w uczeniu się (hipoteza 7);

- kierowanie przez nauczyciela do uczniów komunikatów przekazujących zrozumienie dla doświadczanych przez tych uczniów trudności (hipoteza 8);

- dawanie przez nauczyciela uczniom możliwości decydowania o działaniach w klasie (hipoteza 9).

Hipotezę o różnicy w preferencjach grup osób badanych w roku 2019 oraz 2021 postanowiono zweryfikować także w odniesieniu do każdego zachowania nauczyciela wspierającego uczniowską autonomię, jakie zaplanowano analizować w badaniu.

\section{Metoda badań własnych}

W badaniu zastosowano autorski Inwentarz Wspierania Samodzielności (IWS) składający się z 38 stwierdzeń dotyczących preferencji osób uczących się wobec wspierania ich autonomii w nabywaniu wiedzy i umiejętności. Stwierdzenia sformułowano na podstawie opartej na teorii samookreślenia klasyfikacji przytoczonych przez Reeve'a nauczycielskich zachowań wspierających autonomię uczniów ${ }^{35}$. Każde ze stwierdzeń Inwentarza rozpoczyna się tą samą frazą: „Chciałbym/Chciałabym, aby mój nauczyciel...", następnie podany jest opis zachowania prowadzącego

\footnotetext{
${ }^{35}$ J. Reeve: Autonomy Supportive Teaching...
} 
zajęcia mającego na celu wspieranie samodzielności uczenia się u uczestników zajęć. Wśród stwierdzeń na podstawie ich treści wyróżniono 9 skal: 1) słuchanie uczniów i dawanie im swobody wypowiedzi, 2) zachęcanie uczniów do samodzielności w uczeniu się, 3) dawanie uczniom możliwości decydowania o działaniach w klasie, 4) umożliwianie uczniom decydowania o sposobie wykonywania zadań, 5) wspieranie samodzielności uczniów w rozwiązywaniu problemów, 6) podawanie uczniom informacji zwrotnej o tym, na jakim poziomie wykonali zadania, 7) kierowanie do uczniów komunikatów świadczących o zrozumieniu doświadczanych przez tych uczniów trudności, 8) kierowanie do uczniów komunikatów motywujących do pracy oraz przekazujących wiarę w możliwości uczniów, 9) uzasadnianie wyboru proponowanego uczniom sposobu działania. Oceny każdego ze stwierdzeń Inwentarza uczestnik badań dokonuje za pomocą wyboru jednej z 7 odpowiedzi: „zdecydowanie nie”(0 pkt), „nie” (1 pkt), „raczej nie” (2 pkt), „trudno powiedzieć” (3 pkt), „raczej tak” (4 pkt), „tak” (5 pkt) oraz „zdecydowanie tak" (6 pkt). Wynikiem dla każdej skali jest średnia arytmetyczna sumy punktów za oceny stwierdzeń, które do niej należą. Wynik każdej ze skal Inwentarza oraz jego wynik ogólny mieści się więc w zakresie od 0 do 6. Im ten wynik jest wyższy, tym wyższe deklarowane preferencje wobec ocenianego sposobu wspierania autonomii w uczeniu się. Szczegółowe dane dotyczące rzetelności Inwentarza oraz jego skal zamieszczono w tabeli 1. Ze względu na wartości skośności i kurtozy rozkładu uzyskanych odpowiedzi dane na temat rzetelności grup stwierdzeń przedstawiono w postaci korelacji rho Spearmana.

Tabela 1

Charakterystyka grup stwierdzeń Inwentarza Wspierania Samodzielności (IWS) wykorzystanego w badaniach własnych

\begin{tabular}{l|c|c|c|c}
\hline \multirow{2}{*}{$\begin{array}{c}\text { Skala Inwentarza Wspierania } \\
\text { Samodzielności }\end{array}$} & $\begin{array}{c}\text { Liczba } \\
\text { stwierdzeń }\end{array}$ & $\begin{array}{c}\text { Numery } \\
\text { stwierdzeń }\end{array}$ & \begin{tabular}{c} 
rho Spearmana \\
\cline { 4 - 5 } korelacja \\
z całością
\end{tabular} & $\begin{array}{c}\text { średnia } \\
\text { korelacja } \\
\text { między } \\
\text { pozycjami }\end{array}$ \\
\hline $\begin{array}{l}\text { Słuchanie uczniów oraz dawanie } \\
\text { im swobody wypowiedzi (S) }\end{array}$ & 5 & $1,2,3,4,32$ & 0,685 & 0,397 \\
\hline $\begin{array}{l}\text { Zachęcanie uczniów do } \\
\text { samodzielności w uczeniu się (Z) }\end{array}$ & 5 & $5,6,7,15,16$ & 0,774 & 0,403 \\
\hline $\begin{array}{l}\text { Dawanie uczniom możliwości } \\
\text { decydowania o działaniach } \\
\text { w klasie (DD) }\end{array}$ & 5 & $8,9,12,13$, & 0,701 & 0,363 \\
\hline
\end{tabular}


cd. tab. 1

\begin{tabular}{|c|c|c|c|c|}
\hline \multirow[b]{2}{*}{$\begin{array}{l}\text { Skala Inwentarza Wspierania } \\
\text { Samodzielności }\end{array}$} & \multirow[b]{2}{*}{$\begin{array}{l}\text { Liczba } \\
\text { stwierdzeń }\end{array}$} & \multirow[b]{2}{*}{$\begin{array}{l}\text { Numery } \\
\text { stwierdzeń }\end{array}$} & \multicolumn{2}{|c|}{ rho Spearmana } \\
\hline & & & $\begin{array}{l}\text { korelacja } \\
\text { z całością }\end{array}$ & $\begin{array}{l}\text { średnia } \\
\text { korelacja } \\
\text { między } \\
\text { pozycjami }\end{array}$ \\
\hline $\begin{array}{l}\text { Umożliwianie uczniom } \\
\text { decydowania o sposobie } \\
\text { wykonywania zadań (DW) }\end{array}$ & 2 & 10,11 & 0,645 & 0,580 \\
\hline $\begin{array}{l}\text { Wspieranie samodzielności uczniów } \\
\text { w rozwiązywaniu problemów (RP) }\end{array}$ & 8 & $\begin{array}{l}17,18,19,20 \\
21,22,23 \\
24\end{array}$ & 0,796 & 0,326 \\
\hline $\begin{array}{l}\text { Podawanie uczniom informacji } \\
\text { zwrotnej o tym, na jakim poziomie } \\
\text { wykonali zadania (IZ) }\end{array}$ & 2 & 25,26 & 0,572 & 0,501 \\
\hline $\begin{array}{l}\text { Kierowanie do uczniów } \\
\text { komunikatów świadczących } \\
\text { o zrozumieniu i współczuciu } \\
\text { wobec doświadczanych przez tych } \\
\text { uczniów uczuć i trudności (WZ) }\end{array}$ & 2 & 27,28 & 0,771 & 0,673 \\
\hline $\begin{array}{l}\text { Kierowanie do uczniów } \\
\text { komunikatów motywujących do } \\
\text { pracy oraz przekazujących wiarę } \\
\text { w możliwości uczniów (M) }\end{array}$ & 6 & $\begin{array}{l}29,30,31 \\
33,37,38\end{array}$ & 0,821 & 0,498 \\
\hline $\begin{array}{l}\text { Uzasadnianie wyboru } \\
\text { proponowanego uczniom sposobu } \\
\text { działania (U) }\end{array}$ & 3 & $34,35,36$ & 0,670 & 0,707 \\
\hline
\end{tabular}

Wartości wszystkich korelacji pokazanych w tabeli 1 wskazują na istotny $(p<0,05)$ dodatni związek sumarycznego wyniku poszczególnych skal z wynikiem ogólnym Inwentarza. Siła tego związku dla wszystkich skal okazała się wysoka. W przypadku analizowanych skal średnia korelacja między pozycjami okazała się istotna i dodatnia w przypadku czterech skal siła tej korelacji była wysoka, w przypadku pięciu skal - przeciętna ${ }^{36}$. Uzyskane wartości współczynników korelacji wskazują na akceptowalną rzetelność narzędzia wykorzystanego w badaniach własnych.

W badaniach własnych dane uzyskano od 224 osób - studentów kierunków: pedagogika, edukacja artystyczna w zakresie sztuki muzycznej oraz projektowanie przestrzeni wirtualnej. Średni wiek uczestników

${ }^{36}$ Interpretację siły związku podaję za: S. Juszczyk: Statystyka dla pedagogów. Zarys wykładu. Adam Marszałek, Toruń 2001, s. 167, 170-173. 
badań to 21,8 lat $(S D=3,97 ; N=224)$. Pomiaru za pomocą Inwentarza dokonano dwukrotnie: w roku 2019 oraz 2021; pomiary przeprowadzono w różnych grupach uczestników, ale u osób będących w podobnym wie$\mathrm{ku}$ i studiujących na tych samych kierunkach. Grupa badanych w roku 2019 liczyła 137 osób ( $M=21,7$ lat; $S D=2,94$ dla $N=137)$ - 94 kobiety oraz 40 mężczyzn (odpowiednio 70,1\% oraz 29,9\% dla $N=134$ ), a także 3 osoby, które nie dostarczyły danych na temat swojej płci. W grupie badanej w roku 2021 było 87 osób, których przeciętny wiek wyniósł 21,98 lat $(S D=5,48 ; N=87)$. Spośród uczestników tej grupy płeć podały 72 osoby, w tym 59 kobiet (81,9\%) oraz 13 mężczyzn $(18,1 \%)$.

\section{Wyniki badań własnych}

\section{Nauczycielskie zachowania wspierające autonomię ucznia najchętniej i najmniej chętnie preferowane przez uczestników badań}

Wynik ogólny uzyskany przez uczestników badań w Inwentarzu Wspierania Samodzielności oraz wyniki w poszczególnych skalach tego narzędzia zestawiono na rysunku 1.

Średnia arytmetyczna wyniku ogólnego Inwentarza Wspierania Samodzielności dla wszystkich osób badanych wyniosła 4,64 (SD =-0,66). Rozkład wyniku ogólnego jest przesunięty w stronę rezultatów wysokich (skośność wynosi -0,70). Uzyskane dane wskazują na wysoki stopień preferencji ogółu badanych wobec wspierania przez nauczyciela ich poziomu samodzielności w uczeniu się.

Preferencje uczestników badań dotyczące nauczycielskich zachowań wzmacniających autonomię uczenia się zestawiono ze średnimi arytmetycznymi sum punktów uzyskanych za odpowiedzi na stwierdzenia należące do poszczególnych skal Inwentarza. Spośród 9 analizowanych w Inwentarzu grup zachowań nauczyciela nakierowanych na wspieranie autonomii ucznia osoby badane wskazały jako najbardziej przez siebie preferowane słuchanie uczniów i dawanie im swobody wypowiedzi $(M=4,83)$. Oceny badanych wskazywały na preferowanie w wysokim stopniu również takich grup czynności nauczyciela, jak: podawanie uczniom informacji zwrotnej o tym, na jakim poziomie wykonali zadania $(M=4,77)$, kierowanie do uczniów komunikatów motywujących do pracy oraz przekazujących wiarę w możliwości uczniów $(M=4,76)$, a także uzasadnianie wyboru proponowanego uczniom sposobu działania $(M=4,73)$. 


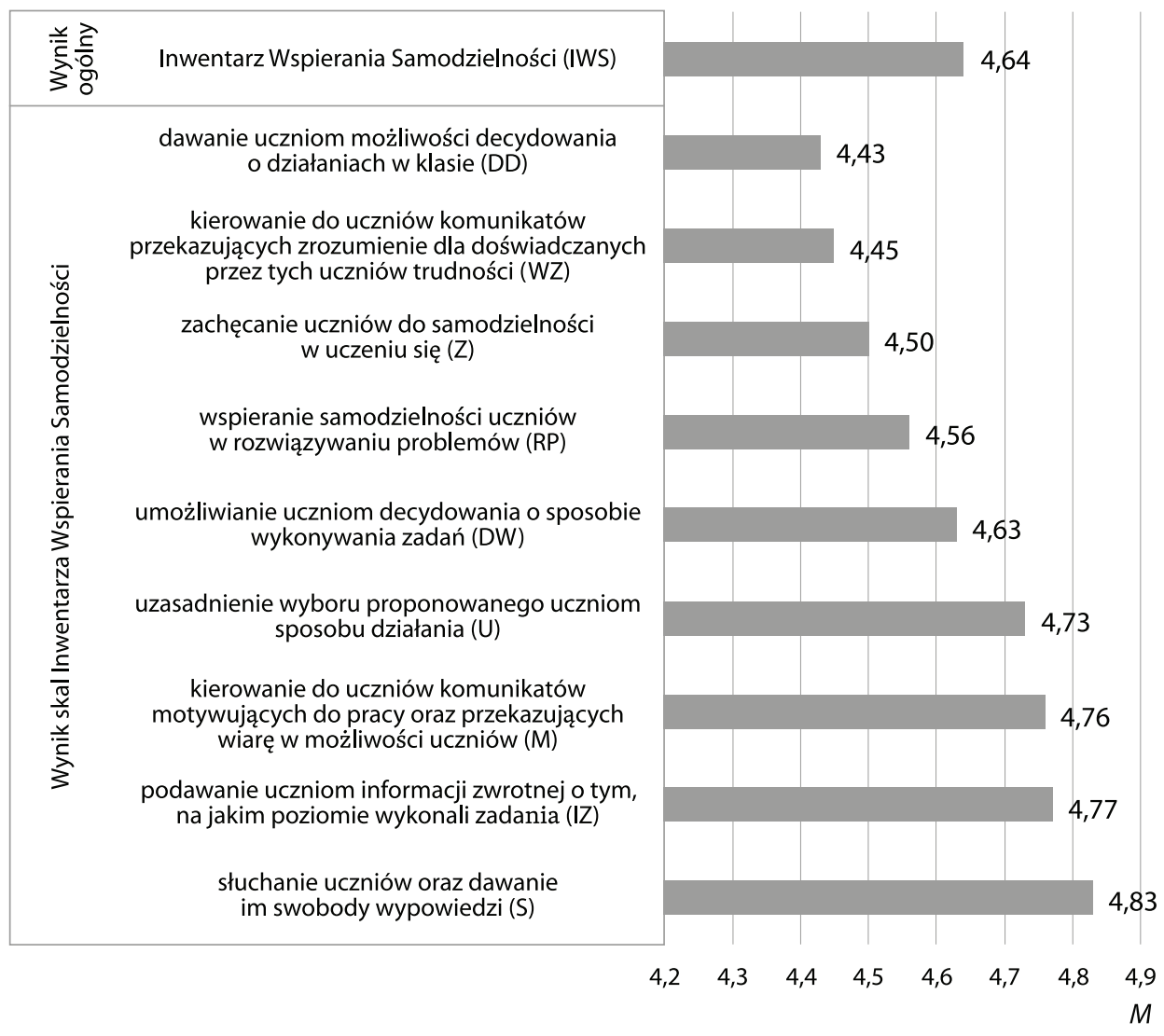

Rys. 1. Preferencje badanych wobec grup nauczycielskich zachowań wspierających autonomię uczących się w nabywaniu wiedzy i umiejętności (wartości średnich arytmetycznych wyniku badania za pomocą Inwentarza Wspierania Samodzielności).

Grupami zachowań nauczyciela wzmacniających samodzielność uczenia się uczestników zajęć preferowanymi przez badanych, w mniejszym jednak stopniu, okazały się: umożliwianie uczniom decydowania o sposobie wykonywania zadań $(M=4,63)$, dawanie uczniom możliwości decydowania o działaniach w klasie $(M=4,43)$, kierowanie do uczniów komunikatów przekazujących zrozumienie dla doświadczanych przez tych uczniów trudności $(M=4,45)$, zachęcanie uczniów do samodzielności w uczeniu się $(M=4,5)$.

Grupą nauczycielskich zachowań wspierających autonomiczne uczenie się uczestników zajęć preferowaną przez badanych, lecz w najmniejszym stopniu, okazało się dawanie uczniom możliwości decydowania o działaniach w klasie $(M=4,43)$.

Analizie poddano także średnie arytmetyczne liczby punktów uzyskanych przez uczestników badań za odpowiedzi na pojedyncze stwierdzenia Inwentarza Wspierania Samodzielności. Dane te pokazano w tabeli 2. 
Preferencje uczących się..

s. $15 \mathrm{z} 28$

$N$
$\pi$
0
0
0
$\pi$

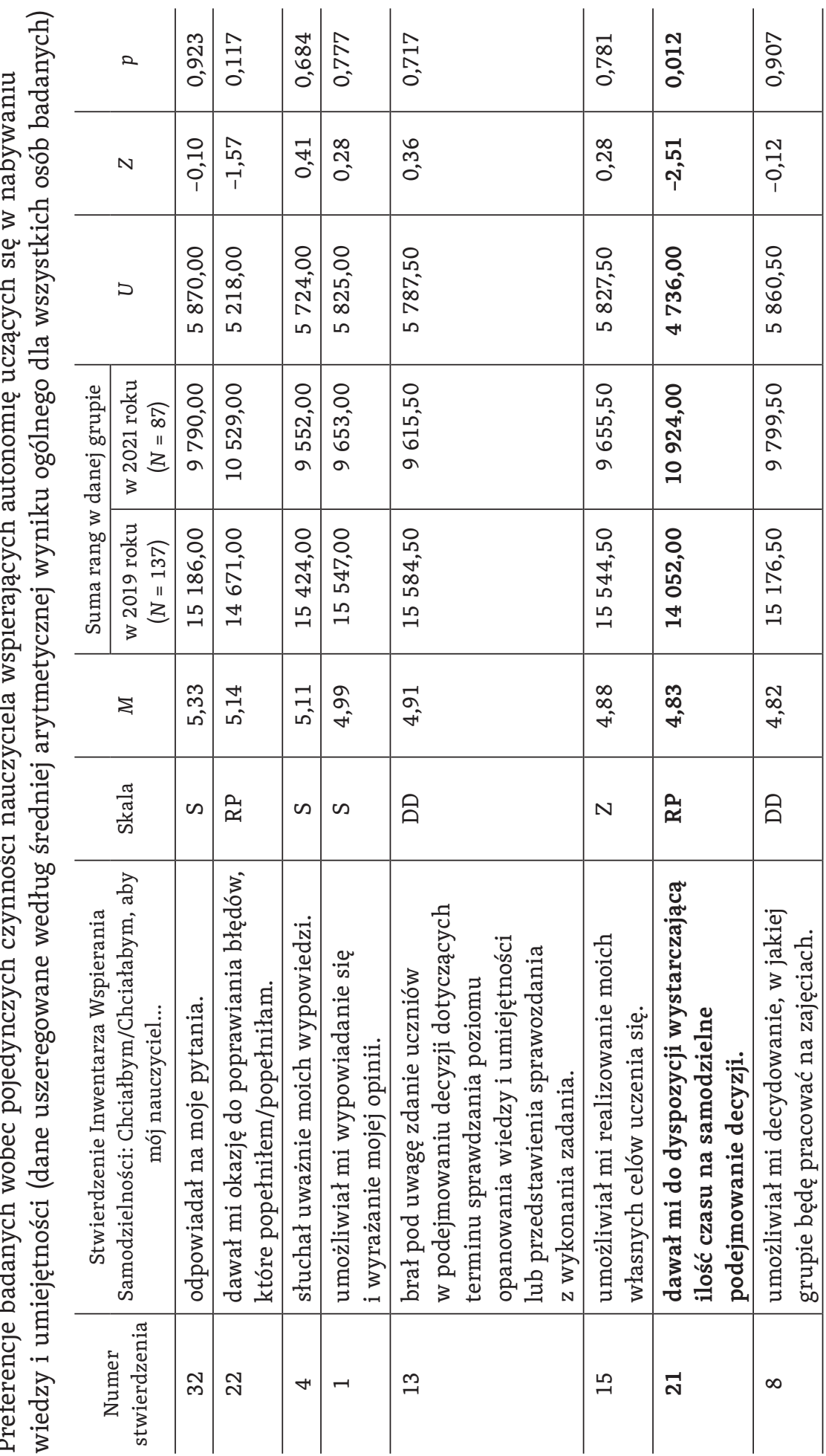




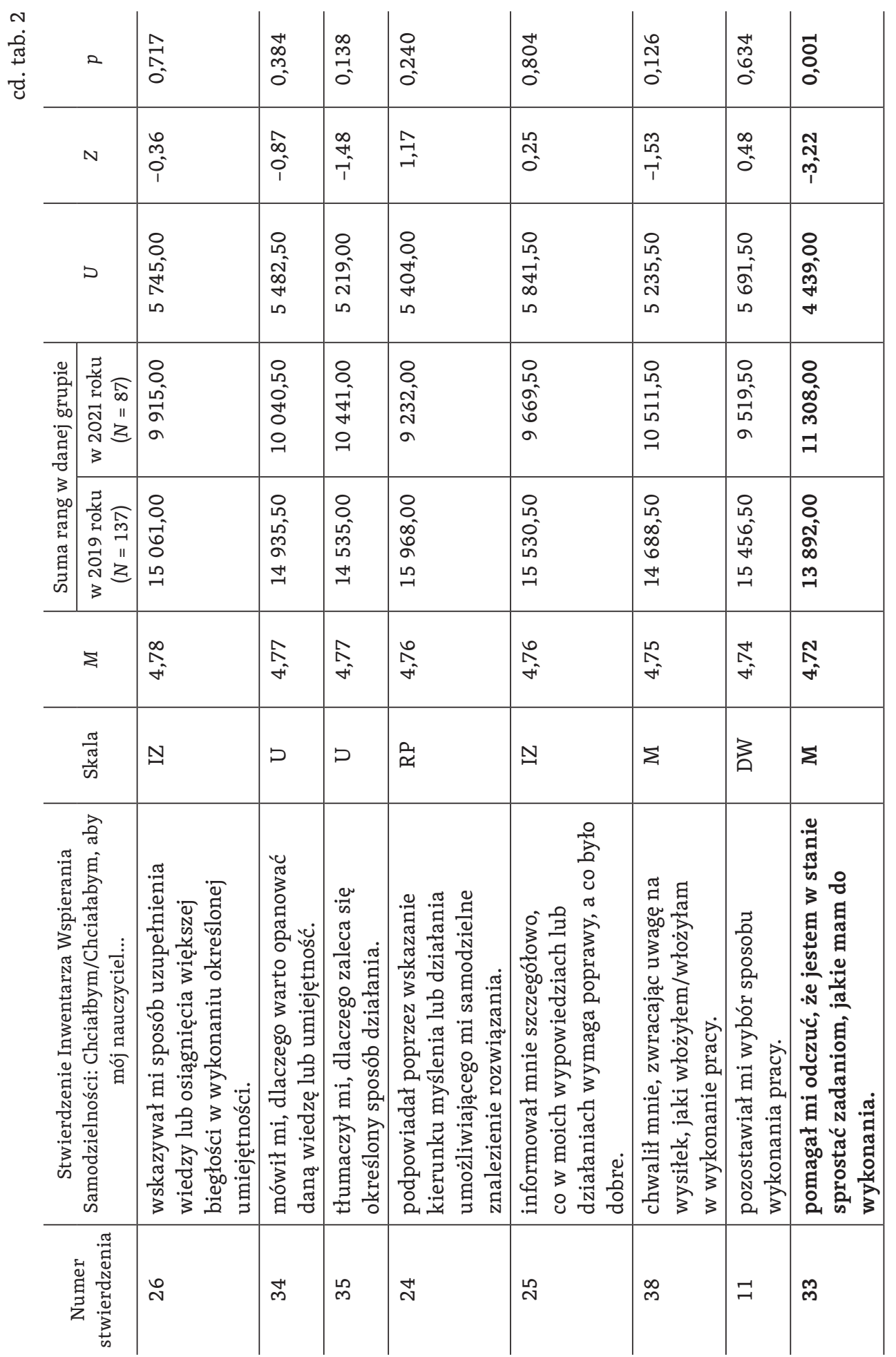


Preferencje uczących się...

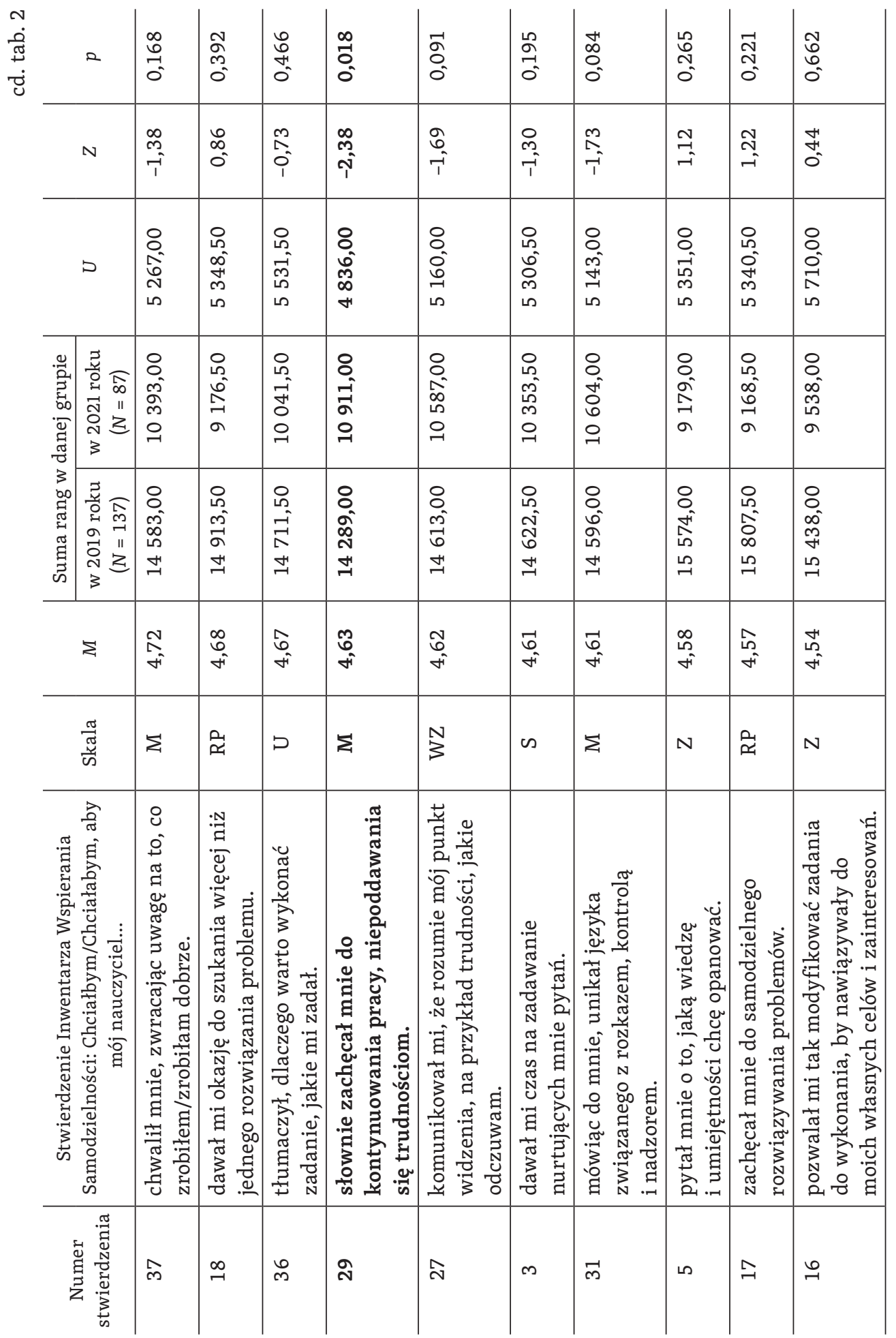




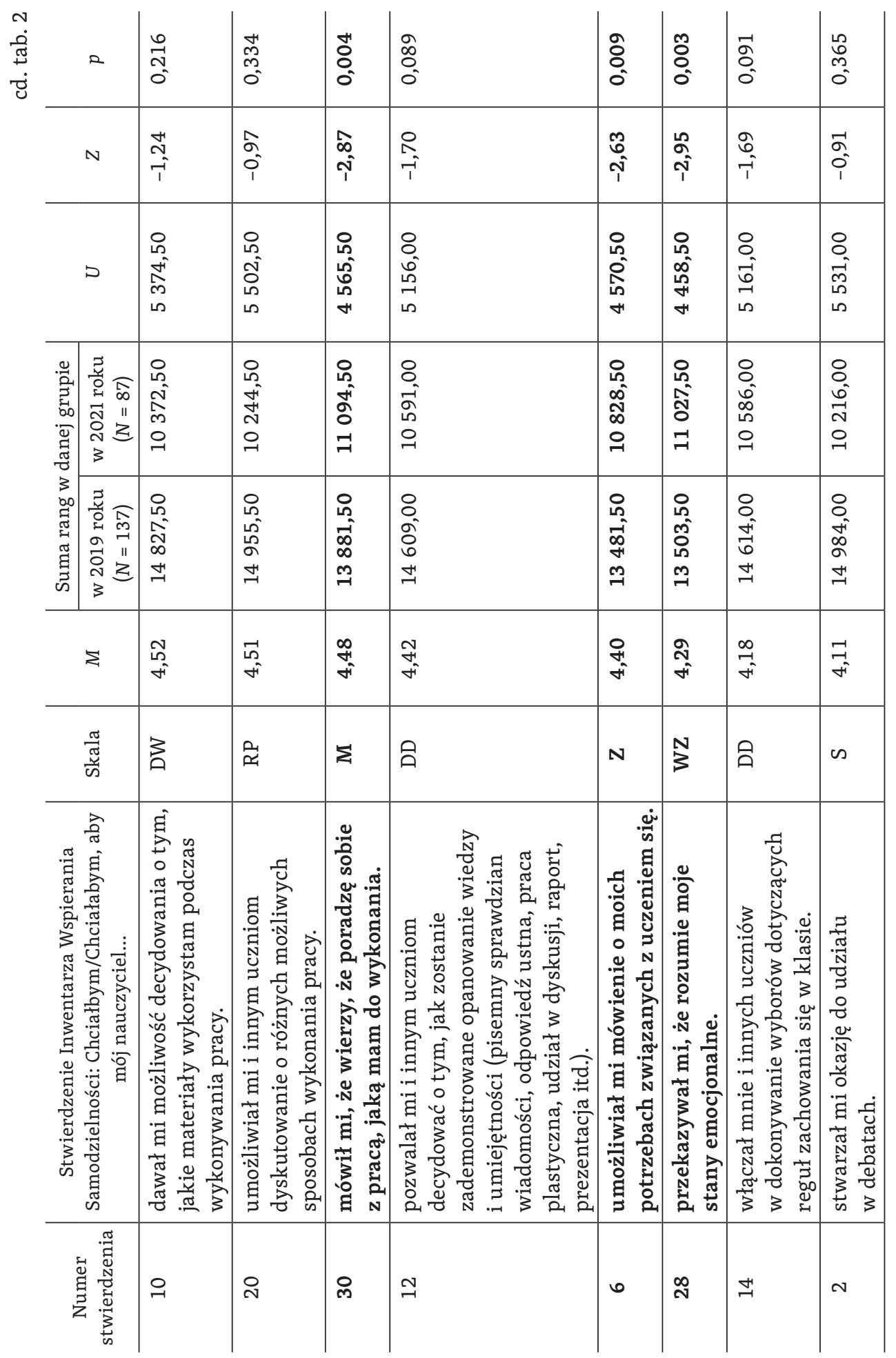


Preferencje uczących się...

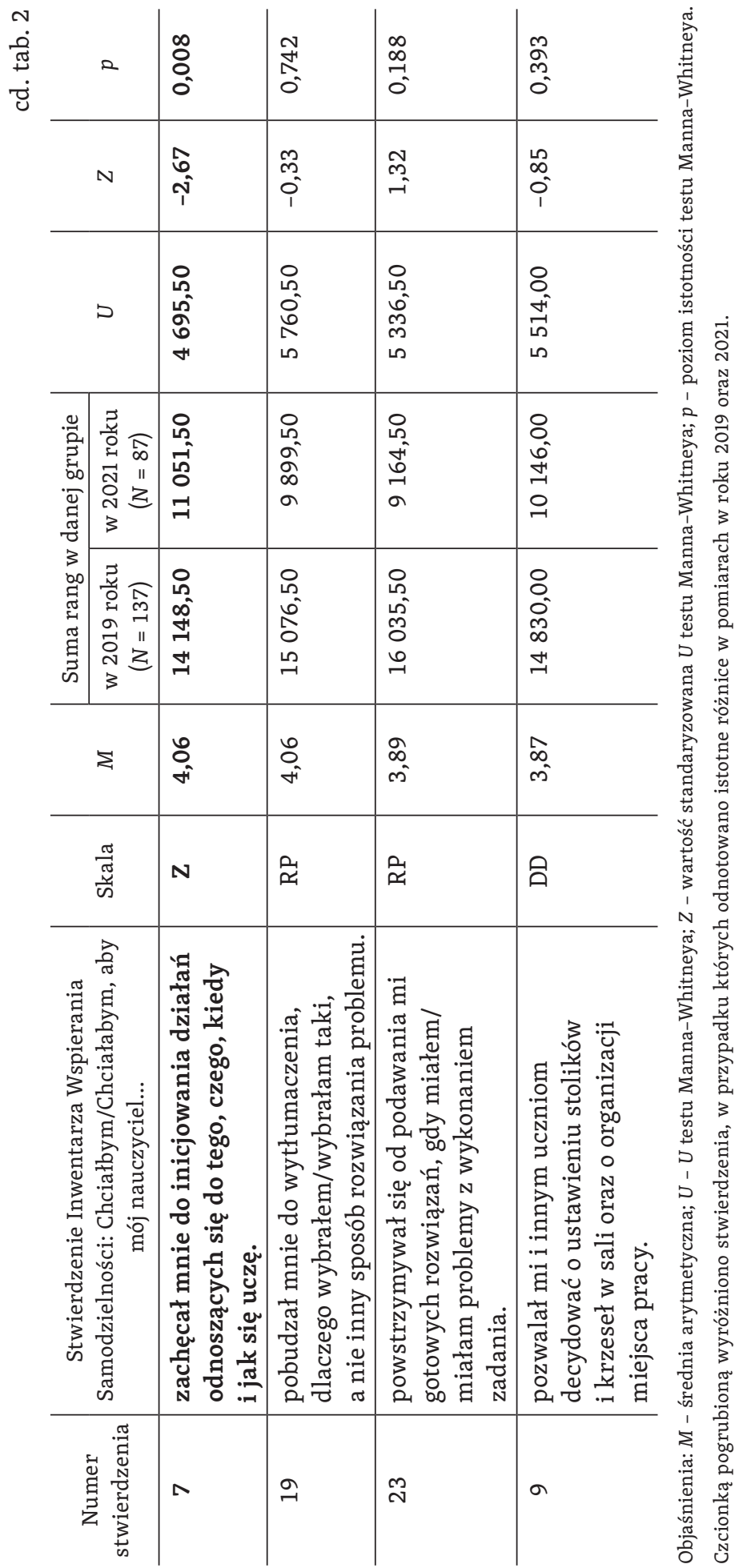


Zachowaniami nauczyciela wspierającymi samodzielność uczniów w nabywaniu wiedzy i umiejętności najbardziej preferowanymi przez uczestników badań okazały się: odpowiadanie na pytania uczniów $(M=5,33)$, dawanie uczniom okazji do poprawiania błędów, które popełnili $(M=5,14)$, uważne słuchanie wypowiedzi uczniów $(M=5,11)$, umożliwianie uczniom wypowiadania opinii $(M=4,99)$, branie pod uwagę opinii uczniów w podejmowaniu decyzji dotyczących terminu sprawdzania poziomu opanowania wiedzy i umiejętności lub przedstawienia sprawozdania $\mathrm{z}$ wykonania zadania $(M=4,91)$.

Nauczycielskimi działaniami wspierającymi uczniowską autonomię w uczeniu się, które osoby badane preferowały w najmniejszym stopniu, były: pozwalanie uczniom, by decydowali o ustawieniu stolików i krzeseł w sali oraz o organizacji miejsca pracy $(M=3,87)$, powstrzymywanie się od podawania uczniom gotowych rozwiązań, gdy mają oni problemy z wykonaniem zadania $(M=3,89)$, pobudzanie uczniów do wytłumaczenia, dlaczego wybrali taki, a nie inny sposób rozwiązania problemu $(M=4,06)$, zachęcanie uczniów do inicjowania działań odnoszących się do tego, czego, kiedy i jak się uczą $(M=4,06)$ oraz stwarzanie uczniom okazji do udziału w debatach $(M=4,11)$.

\section{Różnice w wynikach pomiarów preferencji nauczycielskich zachowań wspierających autonomię uczenia się w grupach osób badanych w 2019 oraz 2021 roku}

Hipotezy dotyczące różnic w wynikach pomiarów preferencji wobec nauczycielskich zachowań wspierających autonomię uczenia się uzyskanych w grupach badanych w 2019 roku (przed pandemią COVID-19) oraz 2021 roku (po 18 miesiącach trwania pandemii) weryfikowano za pomocą testu U Manna-Whitneya. Test ten wybrano ze względu na wysokie wartości skośności i kurtozy rozkładu uzyskanych wyników. Grupami czynności nauczyciela bardziej preferowanymi przez osoby badane w 2021 roku niż przez osoby badane w roku 2019 okazały się: kierowanie do uczniów komunikatów motywujących do pracy i przekazujących wiarę w możliwości uczniów $(U=4754 ; Z=2,31 ; p=0,02)$ oraz kierowanie do uczniów komunikatów przekazujących zrozumienie dla doświadczanych przez tych uczniów trudności $(U=4547,5$; $Z=2,76 ; p=0,006$ ). Potwierdzono więc prawdziwość hipotez 3 oraz 8 . W przypadku preferencji wobec pozostałych analizowanych grup zachowań nauczyciela mających na celu wspieranie samodzielności uczniów w nabywaniu wiedzy i umiejętności nie stwierdzono różnic w pomiarach dokonanych w grupie badanej w roku 2019 i w grupie badanej w roku 2021. 
Weryfikacji hipotez dotyczących różnic między oceną preferencji wobec pojedynczych zachowań nauczyciela wspierających samodzielność uczących się w opanowywaniu wiedzy i umiejętności dokonano za pomocą testu U Manna-Whitneya. Uzyskane rezultaty analiz zestawiono w tabeli 2. Badani w roku 2021 od uczestników badania z roku 2019 różnili się pod względem preferencji wobec 7 spośród 38 analizowanych zachowań nauczyciela mających na celu wspieranie uczniowskiej samodzielności w opanowywaniu wiedzy i umiejętności. Dane wskazują, że w 2021 roku badani deklarowali wyższe preferencje niż uczestnicy badań z roku 2019 wobec następujących zachowań nauczyciela:

- dawanie uczniom odczuć, że są w stanie sprostać zadaniom, jakie mają do wykonania $(U=4439 ; Z=-3,22 ; p=0,001)$;

- przekazywanie uczniom, że jest się świadomym doświadczanych przez nich emocji $(U=4458,5 ; Z=-2,95 ; p=0,003)$;

- dzielenie się z uczniami wiarą, że poradzą sobie z pracą, jaką mają do wykonania $(U=4565,5 ; Z=-2,87 ; p=0,004)$;

- zachęcanie uczniów do inicjowania działań odnoszących się do tego, czego, kiedy i jak się uczą ( $U=4695,5 ; Z=-2,67 ; p=0,008)$;

- umożliwianie uczniom mówienia o potrzebach, jakie odczuwają w związku z uczeniem się $(U=4570,5 ; Z=-2,63 ; p=0,009)$;

- dawanie uczniom do dyspozycji wystarczającej ilości czasu na samodzielne podejmowanie decyzji $(U=4736 ; Z=-2,51 ; p=0,012)$;

- słowne zachęcanie uczniów do kontynuowania pracy, niepoddawania się trudnościom $(U=4$ 836; $Z=-2,38 ; p=0,018)$.

Grupy badane w latach 2019 oraz 2021 dobrano tak, by obejmowały osoby w podobnym wieku oraz na tym samym poziomie edukacji, a także na tych samych kierunkach studiów. Oba pomiary nie były jednak dokonane u tych samych osób. Aby dodatkowo zweryfikować uzyskane dane, grupie osób biorących udział w badaniach w roku 2021 zadano dwa pytania: „Czy spośród opisanych [w Inwentarzu - A.S.] zachowań nauczyciela są takie, które zacząłeś/zaczęłaś preferować w większym stopniu w ciągu ostatnich 12 miesięcy? Jeśli tak, wskaż te zachowania” oraz „Czy wśród opisanych [w Inwentarzu - A.S.] zachowań nauczyciela są takie, które zacząłeś/zaczęłaś preferować w mniejszym stopniu w ciągu ostatnich 12 miesięcy? Jeśli tak, wskaż te zachowania". Uczestników badań poproszono, by w każdym przypadku ograniczyli się do wskazania maksymalnie 3 zachowań nauczyciela.

$\mathrm{Na}$ pytanie o to, czy badani w ciągu ubiegłych 12 miesięcy zaczęli bardziej preferować wybrane zachowania nauczyciela wspierające uczniowską autonomię nabywania wiedzy i umiejętności, udzielono w sumie 29 odpowiedzi, w tym 8 osób odpowiedziało: „nie”. Badania, którzy udzielili odpowiedzi twierdzącej, wymienili następujące czynności nauczyciela: 
1. Chwalenie ze zwracaniem uwagi na to, co uczący się zrobił dobrze, chwalenie ze zwracaniem uwagi na wysiłek włożony w wykonanie pracy (po 8 wskazań).

2. Uzasadnianie, dlaczego należy wykonać proponowane zadania, oraz budowanie motywacji uczniów - zachęcanie do pracy (po 6 wskazań).

3. Mówienie uczniowi, że wierzy się, iż poradzi sobie z pracą do wykonania, wsparcie emocjonalne uczniów, odpowiadanie na pytania ucznia (po 4 wskazania).

4. Komunikowanie zrozumienia odczuwanych przez ucznia trudności, umożliwienie uczniowi wypowiadania się i wyrażania opinii, umożliwienie uczniom dyskutowania o różnych możliwych sposobach wykonania pracy, informowanie ucznia, co w jego wypowiedziach lub działaniach wymaga poprawy, komentowanie wypowiedzi ucznia - podawanie informacji zwrotnej, umożliwienie uczniom realizowania własnych celów uczenia się, wskazanie sposobu uzupełniania wiedzy (po 2 wskazania).

Pozostałe czynności nauczyciela wymieniono jednokrotnie.

Badani studenci w odpowiedzi na pytanie, czy są zachowania nauczyciela, które zaczęli preferować w mniejszym stopniu w ubiegłych 12 miesiącach, udzielili w sumie 32 odpowiedzi, w tym 11 odpowiedzi negatywnych. Ci, którzy na pytania odpowiedzieli twierdząco, po 2 razy wymienili nauczycielskie czynności i postawy takie jak: stwarzanie uczniom okazji do udziału w debatach, umożliwianie decydowania o ustawieniu stolików, przekazywanie uczniom zrozumienia wobec doświadczanych przez nich trudności i emocji oraz umożliwianie uczniom wypowiadania własnych opinii. Pozostałe odpowiedzi były wymieniane tylko raz.

Uzyskane wyniki porównania danych dotyczących preferencji wobec nauczycielskich zachowań wspierających autonomię uczenia się u studentów badanych w 2021 roku oraz dwa lata wcześniej wskazują, że preferencje te nie różniły się istotnie w przypadku 7 z 9 analizowanych grup zachowań prowadzącego zajęcia. Badani w 2021 roku w większym stopniu niż badani w roku 2019 preferowali: bycie wysłuchanym przez nauczyciela i posiadanie możliwości swobody wypowiedzi, nauczycielskie zachęty do samodzielności w uczeniu się, dawanie uczestnikom zajęć przez nauczyciela możliwości decydowania o działaniach $\mathrm{w}$ klasie oraz o sposobie wykonywania zadań, wspieranie samodzielności uczących się w rozwiązywaniu problemów, podawanie uczestnikom zajęć informacji zwrotnej o tym, na jakim poziomie wykonali zadania, oraz uzasadnianie przez nauczyciela wyboru sposobu działania, jaki proponuje uczącym się. Badani w 2021 roku w istotnie wyższym stopniu niż badani w roku 2019 deklarowali preferencje wo- 
bec kierowania do nich przez nauczyciela komunikatów przekazujących zrozumienie trudności doświadczanych podczas uczenia się oraz komunikatów motywujących uczących się do pracy i przekazujących wiarę w ich możliwości.

\section{Podsumowanie i wnioski}

Celem badań własnych opisanych w niniejszym artykule było poznanie poziomu preferencji uczestników zajęć wobec stosowanych przez nauczycieli sposobów wspierania autonomii osób uczących się. Zadano pytania badawcze o: nauczycielskie zachowania wspierające autonomię ucznia najchętniej preferowane przez uczestników badań, nauczycielskie zachowania wspierające autonomię ucznia najmniej chętnie preferowane przez uczestników badań, istnienie różnic w wynikach pomiarów preferencji nauczycielskich zachowań wspierających autonomię uczenia się w grupach osób badanych w 2019 oraz 2021 roku, sposoby wspierania autonomii ucznia przez nauczyciela wskazane przez osoby biorące udział w badaniach w 2021 roku jako te, które są przez nie bardziej preferowane w ubiegłych 12 miesiącach, oraz sposoby wspierania autonomii ucznia przez nauczyciela wskazywane przez uczestników badań w 2021 roku jako te, które zaczęli oni mniej preferować w ubiegłych 12 miesiącach.

Na potrzeby badań skonstruowano, opierając się na założeniach teorii samookreślenia, Inwentarz Wspierania Samodzielności, składający się z 38 stwierdzeń opisujących czynności nauczyciela uważane za pomocne w rozwijaniu uczniowskiej autonomii w opanowywaniu wiedzy i umiejętności. Dane zebrano od 224 osób - studentów kierunków: pedagogika, edukacja artystyczna w zakresie sztuki muzycznej oraz projektowanie przestrzeni wirtualnej. Pierwszą część danych uzyskano w roku 2019 od 137 osób; drugą część danych zebrano w roku 2021 od 87 osób. W składzie grupy z 2021 roku nie znajdowały się osoby, które brały udział w badaniu z roku 2019, badani byli jednak w podobnym wieku i studiowali na tych samych kierunkach, co biorący udział w pomiarze z roku 2019. Uzyskane dane pozwoliły udzielić następujących odpowiedzi na postawione pytania badawcze:

1. Badani stwierdzili, że spośród nauczycielskich zachowań wspierających ich autonomię w uczeniu się najbardziej preferują możliwość bycia wysłuchanym oraz posiadanie swobody wypowiedzi, otrzymywanie informacji zwrotnej o tym, na jakim poziomie wykonali zadania, otrzymywanie komunikatów motywujących do pracy oraz przekazujących wiarę w możliwości uczniów. 
2. Nauczycielskimi zachowaniami wspierającymi samodzielność ucznia w nabywaniu wiedzy i umiejętności, które badani wskazywali jako najmniej chętnie preferowane, okazało się dawanie uczniom możliwości decydowania o działaniach w klasie.

3. Wyniki pomiarów w grupie badanej w roku 2021 wykazały wyższe niż w grupie badanej w roku 2019 preferencje badanych wobec komunikatów nauczyciela motywujących do pracy oraz przekazujących wiarę w możliwości uczących się, a także przekazujących zrozumienie dla doświadczanych przez nich trudności.

4. Odpowiedzi uczestników części badań przeprowadzonej w 2021 roku świadczą o tym, że w czasie pandemii COVID-19 zauważyli oni u siebie wzrost preferencji wobec takich zachowań nauczycieli, jak: docenianie wysiłku i postępu uczniów w uczeniu się, motywowanie do pracy, uzasadnianie proponowanego sposobu działania, odpowiadanie na pytania oraz przekazywanie uczniom wiary w ich możliwości, a także udzielanie uczącym się wsparcia emocjonalnego.

5. Badani w roku 2021 wskazali także, że obniżyły się u nich preferencje wobec takich nauczycielskich zachowań, jak: umożliwienie uczniom udziału w debatach, wypowiadania własnych opinii, decydowania o ustawieniu stolików, a także przekazywanie uczniom zrozumienia doświadczanych przez nich trudności i emocji.

Rezultaty badań własnych pozwalają stwierdzić, że badani w wysokim stopniu preferują sytuacje, w których wspiera się ich samodzielność w uczeniu się. Jest to zgodne ze znanymi z literatury przedmiotu danymi dowodzącymi, że zajęcia wspomagające autonomię uczenia się wzmacniają poczucie motywacji wewnętrznej uczestników oraz doświadczanie przez nich pozytywnych emocji ${ }^{37}$. Wyniki badań własnych wskazują też, że respondenci najbardziej cenią sobie możliwość wyrażania własnych opinii oraz uzyskiwanie wsparcia motywacyjnego oraz emocjonalnego ze strony nauczyciela. Na istotność atmosfery w klasie sprzyjającej poczuciu bycia akceptowanym przez uczestników zajęć zwrócili uwagę już Tanner LeBaron Wallace oraz Hannah C. Sung ${ }^{38}$. Okazywanie uczniom wsparcia oraz zrozumienia dla ich uczuć jest szczególnie ważne w czasach kryzysu, jakim jest pandemia COVID $-19^{39}$. Candice R. Stefanou, Kathleen C. Perencevich, Matthew

${ }^{37}$ E.L. Deci, R.M. Ryan: Optimizing Students' Motivation in the Era of Testing and Pressure...

${ }^{38}$ T.L. Wallace, H.C. Sung: Student Perceptions of Autonomy-Supportive Instructional Interactions in the Middle Grades...

${ }^{39}$ T. Blicki: Jak pracować z uczniem $w$ kryzysie w czasie pandemii COVID-19. W: Edukacja w czasach pandemii wirusa COVID-19... 
DiCintia i Julianne Turner ${ }^{40}$ potwierdzili, że jednym z najefektywniejszych działań we wspieraniu samodzielności uczenia się jest pobudzanie uczestników zajęć do rozwiązywania problemów. Dane zebrane w badaniach własnych pokazały, że ten sposób wspierania autonomii był preferowany przez respondentów w umiarkowanym stopniu.

Rezultaty, jakie uzyskano, wymagają potwierdzenia w badaniach na większej grupie osób zróżnicowanej wiekowo. Mogą być jednak rozszerzająco wykorzystane $\mathrm{w}$ badaniach realizowanych $\mathrm{w}$ ramach projektowanego grantu, a streszczenia głównych wyników mogą być przekazane do praktycznego wykorzystania w nauczaniu podstawowym i średnim. W obecnych czasach - na co wskazują wyniki badań nauczyciele powinni rozważyć możliwość wykorzystywania w większym zakresie takich sposobów wspierania samodzielności uczących się w nabywaniu wiedzy i umiejętności, jak kierowanie do uczestników zajęć komunikatów motywujących, okazujących zrozumienie dla trudności i emocji, jakich doświadczają uczniowie, oraz podkreślających te elementy pracy, które wykonali oni dobrze. W działaniach edukacyjnych należałoby zwrócić szczególną uwagę na wdrażanie uczniów do mniej przez nich preferowanych sytuacji wymagających samodzielności w rozwiązywaniu problemów, a zwłaszcza na konieczność omawiania z nimi rozwiązań, jakie proponują.

\section{Bibliografia}

Assor A., Kaplan H., Roth G.: Choice Is Good, but Relevance Is Excellent: Autonomy-Enhancing and Supressing Teacher Behaviours Predicting Students' Engagement in Schoolwork. „British Journal of Educational Psychology" 2002, vol. 72, s. 261-278. https://doi. org/10.1348/000709902158883.

Benson P.: Teaching and Researching Autonomy in Language Learning. Longman, Harlow 2001.

Beymer P.N., Thomson M.M.: The Effects of Choice in the Classroom: Is There Too Little or Too Much Choice? "Support for Learning” 2015, vol. 30 (2), s. 105-120. https://doi.org/10.1111/1467-9604.12086.

Blicki T.: Jak pracować z uczniem w kryzysie w czasie pandemii COVID-19. W: Edukacja w czasach pandemii wirusa COVID-19. Z dystansem o tym, co robimy obecnie jako nauczyciele. Red. J. Pyżalski. PDF. Edukacja, Warszawa 2020, s. 16-19.

Ciekanski M.: Fostering Learner Autonomy: Power and Reciprocity in the Relationship Between Language Learner and Language Learning Adviser.

${ }^{40}$ C.R. Stefanou et al.: Supporting Autonomy in the Classroom... 
"Cambridge Journal of Education" 2007, vol. 37 (1), s. 111-127. https:// doi.org/10.1080/03057640601179442.

Deci E.L., Ryan R.M.: Optimizing Students' Motivation in the Era of Testing and Pressure: A Self-Determination Theory Perspective. W: Building Autonomous Learners. Perspectives from Research and Practice Using Self-Determination Theory. Eds. W.Ch. Liu, J.Ch.K. Wang, R.M. Ryan. Springer, London 2016, s. 9-30. https://doi.org/10.1007/978-981-287630-0.

Deci E.L., Ryan R.M.: Self-Determination Theory: A Macrotheory of Human Motivation, Development, and Health. "Canadian Psychology” 2008, vol. 49 (3), s. 182-185. https://doi.org/10.1037/a0012801.

Dobrowolski A.B.: Nowa dydaktyka. Oprac. komitet redakcyjny. Wstępem zaopatrzył W. Okoń. Państwowe Zakłady Wydawnictw Szkolnych, Warszawa 1960.

Dumont H., Istance D.: Analiza i tworzenie środowisk uczenia się XXI wieku. W: Istota uczenia się. Wykorzystanie wyników badań w praktyce. Red. H. Dumont, D. Istance, F. Benevides. Wstęp A. Janowski. Tłum. Z. Janowska. Wolters Kluwer Polska, Warszawa 2013, s. 35-59. https://doi. org/10.1787/9789264201606-pl.

Guay F., Ratelle C.F.: Optimal Learning in Optimal Contexts: The Role of Self-Determination in Education. "Canadian Psychology" 2008, vol. 49 (3), s. 233-240. https://doi.org/10.1037/a0012758.

Gulbinskienè D., Masoodi M., Šliogerienè J.: Moodle as Virtual Learning Environment in Developing Language Skills, Fostering Metacognitive Awareness and Promoting Learner Autonomy. „Pedagogika” 2017, T. 127, nr 3, s. 176-185. https://doi.org/10.15823/p.2017.47.

Istance D., Dumont H.: Przyszłość środowisk uczenia się XXI wieku. W: Istota uczenia się. Wykorzystanie wyników badań w praktyce. Red. H. Dumont, D. Istance, F. Benavides. Wstęp A. Janowski. Tłum. Z. Janowska. Wolters Kluwer Polska, Warszawa 2013, s. 479-513. https:// doi.org/10.1787/9789264201606-pl.

Jang H., Reeve J., Halusic M.: A New Autonomy-Supportive Way of Teaching that Increases Conceptual Learning: Teaching in Students' Preferred Ways. "Journal of Experimental Education" 2016, vol. 84 (4), s. 686701. https://doi.org/10.1080/00220973.2015.1083522.

Juszczyk S.: Statystyka dla pedagogów. Zarys wykładu. Adam Marszałek, Toruń 2001.

Kojs W.: Edukacja i pedagogika w społeczeństwie wiedzy - wybrane zagadnienia. „Chowanna” 2012, nr 2 (39), s. 21-37.

Kojs W., Urban-Kojs E.: Spoteczne, osobowe i pedagogiczne aspekty edukacji całożyciowej człowieka. W: Czas społeczny akademickiego uczestnictwa $w$ rozwoju i doskonaleniu civil society: ksiegga jubileuszowa dedykowana profesorowi Andrzejowi Radziewiczowi-Winnickiemu w 65. rocznicę uro- 
dzin. Red. E. Syrek. Wydawnictwo Uniwersytetu Śląskiego, Katowice 2010, s. 312-324.

Komissarouk S., Harpaz G., Nadler A.: Dispositional Differences in Seeking Autonomy-or Dependency-Oriented Help: Conceptual Development and Scale Validation. „Personality and Individual Differences” 2017, vol. 108, s. 103-112. https://doi.org/10.1016/j.paid.2016.12.019.

Kron F.W.: Pedagogika. Kluczowe zagadnienia. Podręcznik akademicki. Przekł. E. Cieślik. Gdańskie Wydawnictwo Psychologiczne, Sopot 2012. Nayernia A.: Development and Validation of an E-teachers' Autonomy-Support Scale: A SEM Approach. „International Journal of Language Studies" 2020, vol. 14 (2), s. 117-134.

Oğuz A.: Developing a Scale for Learner Autonomy Support. „Educational Sciences: Theory and Practice" 2013, vol. 13 (4), s. 2187-2194.

Phithakmethakun M., Chinokul S.: Autonomy-Supportive English Language Instruction: An Experimental Study on Students' Motivation in English Language Classroom. "Language Education and Acquisition Research Network Journal" 2020, nr 1 (13), s. 94-113. https://files. eric.ed.gov/fulltext/EJ1242978.pdf [dostęp: 20.06.2021].

Pierro A. et al.: Regulatory Mode Preferences for Autonomy Supporting Versus Controlling Instructional Styles. „British Journal of Educational Psychology" 2009, vol. 79 (4), s. 599-615. https://doi. org/10.1348/978185409X412444.

Plebańska M., Szyller A., Sieńczewska M.: Edukacja zdalna w czasach COVID-19. Raport z badania. Czerwiec 2020. https://kometa.edu.pl/ uploads/publication/941/24a2_A_a_nauczanie_zdalne_oczami_ nauczycieli_i_uczniow_RAPORT.pdf?v2.8COVID [dostęp:20.06.2021]. Półturzycki J.: Dydaktyka dla nauczycieli. Adam Marszałek, Toruń 1999. Pyżalski J.: Wstęp. W: Edukacja w czasach pandemii wirusa COVID-19. $Z$ dystansem o tym, co robimy obecnie jako nauczyciele. Red. J. Pyżalski. PDF. Edukacja, Warszawa 2020, s. 2-6.

Reeve J.: Autonomy Supportive Teaching: What It Is, How to Do It. W: Building Autonomous Learners. Perspectives from Research and Practice Using Self-Determination Theory. Eds. W.Ch. Liu, J.Ch.K. Wang, R.M. Ryan. Springer, London 2016, s. 129-152. https://doi.org/10.1007/978-981287-630-0.

Sawiński J.P.: Jak zwiększyć skuteczność szkolnej edukacji. Poradnik dla nauczycieli i edukatorów. Cz. 2. Difin, Warszawa 2016.

Skinner E.A., Belmont M.J.: Motivation in the Classroom: Reciprocal Effects of Teacher Behavior and Student Engagement Across the School Year. "Journal of Educational Psychology" 1993, vol. 85 (4), s. 571-581. https://doi.org/10.1037/0022-0663.85.4.571.

Stone D.N., Deci E.L., Ryan R.M.: Beyond Talk: Creating Autonomous Motivation through Self-Determination Theory. "Journal of Genera Man- 
agement" 2009, vol. 34 (3), s. 75-91. https://doi.org/10.1177/03063070 0903400305.

Stefanou C.R. et al.: Supporting Autonomy in the Classroom: Ways Teachers Encourage Student Decision Making and Ownership. „Educational Psychologist" 2004, vol. 39 (2), s. 97-110. https://doi.org/10.1207/ s15326985ep3902_2.

Wallace T.L., Sung H.C.: Student Perceptions of Autonomy-Supportive Instructional Interactions in the Middle Grades. "The Journal of Experimental Education" 2017, vol. 85 (3), s. 425-449. https://doi.org/10.108 0/00220973.2016.1182885.

Yeh Y.L., Lau Y.J.: Fostering Student Autonomy in English Learning Through Creations in a 3D Virtual World. „Educational Technology Research and Development" 2018, vol. 66, s. 693-708.

Zhao J., Qin Y.: Perceived Teacher Autonomy Support and Students' Deep Learning: The Mediating Role of Self-Efficacy and the Moderating Role of Perceived Peer Support. „Frontiers in Psychology” 2021, s. 1-11. https:// doi.org/10.3389/fpsyg.2021.652796. 